FEDERICO FERRETTI - BA, MA, PhD, Associate Professor, University College Dublin, School of Geography, Belfield, Newman Building, Room H015, federico.ferretti@ucd.ie, http://www.ucd.ie/research/people/geography/drfedericoferretti/; tel. +3531 716 8176, +39 340 4944825; ORCID ID: 0000-0002-5446-6522; Scopus: 55540917000

\title{
Travelling in lifeworlds: new perspectives on (post) humanism, situated subjectivities and agency from a travel diary
}

Abstract: This paper argues for building bridges between humanistic geographical traditions and current post-humanistic approaches destabilising the centrality and the very epistemological status of the human subject. Extending and putting in relation recent literature highlighting the possible continuities over the ruptures between these traditions and feminist scholarship arguing for the political relevancy of intimate writings and emotional geographies, I analyse an exceptional archival document recently discovered in the Anne Buttimer archives at University College Dublin: Buttimer's travel diary relating her 1965-1966 trips to France and continental Europe, when she began to build her transnational and multilingual scholarly networks. Buttimer was one of the first geographers to explore "lifeworlds", and this document simultaneously reveals the emotional experiences of discovery and the role played in that by circumstances and external agencies decentring and problematising subjective intentionality. These journeys profoundly affected Buttimer's early scholarly career, leading to her first critical questionings of the institutions in which she was inserted. Complementing recent claims for a "new humanism" taking onboard the critiques coming from scholars informed by “anti/posthumanism”, I argue that the mobility, situatedness and relational nature of inbecoming subjects, at the same time acting and being acted, allows for reconsidering human F. Ferretti, 2020: "Travelling in scholarly lifeworlds: new perspectives on (post)humanism, situated subjectivities and agency from a travel diary", Annals of the American Association of Geographers doi: 10.1080/24694452.2020.1715197 
subjectivity and agency in more complex contexts. The document that I analyse shows how human subjectivity can be considered as an actor in relational and circumstantial encounters, contextually building lifeworlds, rather than a despotic monopolist of knowledge and agency as suggested by some simplified narratives.

Keywords: Anne Buttimer; post-humanism; emotional geographies; human subjectivities; intimate writings

This paper addresses the stories told by a material object to discuss possible relations between humanistic geographies and later developments in post-phenomenological and post-humanist scholarship, around the notions of lifeworlds, circumstances, situated and relational subjectivities and agency. Phenomenology, existentialism and humanism have often overlapped in geography, although they could hardly be identified as the same phenomenon (Pickles 1987; Ash and Simpson 2016). Recently retrieved at UCD from the documents of an eminent representative of these tendencies, Anne Buttimer (1938-2017), the travel diary that I analyse relates Buttimer's first meetings with French-speaking scholars who played a primary role in informing her ideas on social geography and lifeworlds. The diary is a small-format copybook with rings and comprises 132 typewritten pages (approximately 25,000 words); it includes pictures and postcards related to three European journeys taken by Buttimer, who was then a young postdoctoral scholar and Dominican nun in Seattle: the first in France, Germany, Austria, Switzerland, Belgium and the Netherlands from 24 June to 23 July 1965; the second in Yugoslavia, Italy, Belgium and England from 31 August to 24 September 1965; and the third in France and Belgium from 4 March to 10 July 1966. Though this can be considered a relatively traditional archival source, it reveals stories about the intersection between the F. Ferretti, 2020: "Travelling in scholarly lifeworlds: new perspectives on (post)humanism, situated subjectivities and agency from a travel diary", Annals of the American Association of Geographers doi: 10.1080/24694452.2020.1715197 
author's religious, scholarly and intellectual life, related to the fact that Buttimer was one of the first lifeworld theorists in geography, and provides an opportunity to revisit the relation between Buttimer's work and contemporary debates within geography.

The aim of this paper is to show links and build bridges between humanistic and posthumanistic traditions, by addressing decentred subjectivities and agencies which can expose how the subject as understood by some humanistic geographers like Buttimer was never an exclusionary and despotic entity. This subject is constantly submitted to circumstances, affects and multiple agencies in its being built through concrete and material experiences. This extends current claims for linking humanism and post/anti-humanism (Simonsen 2012) and seeks dialogue with recent post-humanist scholarship paying attention to "material situatedness .... in bringing the material and affective registers of social life to the fore" (Williams et al. 2019, 637). These authors argue for resisting "a strict and antagonistic division between the work of 'theory' and the work of 'practice'" (Williams et al. 2019, 640), while considering the act of writing as an action which is not external to the matter addressed (Roberts 2019) and should be understood in its circumstances and practicalities. I contend that this is exactly what is shown by Buttimer's travel notes as discussed below.

My argument is twofold. First, biographical and autobiographical documentary sources like diaries are effective in understanding the construction of scholarly lifeworlds, which account for both the theoretical contents of scholars' intellectual work and their personal and embodied interactions with the world. Considering both humanistic claims for "human freedom" (Buttimer 1993) and post-phenomenological and post-humanistic claims decentring and destabilising subjective agencies (Castree and Nash 2006; Lorimer 2009), I read this document F. Ferretti, 2020: "Travelling in scholarly lifeworlds: new perspectives on (post)humanism, situated subjectivities and agency from a travel diary", Annals of the American Association of Geographers doi: 10.1080/24694452.2020.1715197 
to rethink a more-than-phenomenological and less-than-circumstantial interconnection between subjects and events. In this interconnection, the relational and situated nature of subjectivities, as well as their mobilities and in-becomingness revealed by each subject's lived experiences, allow keeping room for human freedom and agency without underplaying the role of external (human and non-human) agencies and contingencies. In Buttimer's diary, displacements were organised day by day by the narrating subject, implying constant mobility and instability: this emphasises the centrality of sensorial, embodied and emotional experiences in the subject's formation, constantly negotiated with other people or with events and physical places. In these negotiations, an important role was played by Buttimer's religious experience as a member of transnational networks within the Dominican order, which created cosmopolite and multilingual occasions to build her intellectual lifeworlds and often contrasted other more secular circumstances as I explain below. Without coming back to the classical centrality of the subject, this helps understanding non-representationally how intellectual life is also shaped by relations and circumstances interacting with subjective agency and creativity and how people (eventually scholars) build relationally their social and intellectual worlds through multifaceted life experiences.

Second, this document substantiates feminist claims about emotional geographies and intimate writings by showing that personal writing (eventually keeping a diary) can exert a scholarly and political subversive function in challenging the powers in place. While studying personal diaries matches well-established claims from feminist scholars to engage with "overlooked day-to-day practices through which difference and power work" (Smith 2016, 134), an established literature has shown how writing a diary is a varied and complex exercise, one which can lead to individual awareness and growth (Lejeune 2009). As scholars like Philippe F. Ferretti, 2020: "Travelling in scholarly lifeworlds: new perspectives on (post)humanism, situated subjectivities and agency from a travel diary", Annals of the American Association of Geographers doi: 10.1080/24694452.2020.1715197 
Lejeune demonstrated, the habit of writing diaries was progressively spread with mass schooling and was especially conceived by institutions such as the school, the family and the church as a good activity for young girls and women to steer and discipline their "irrational" impulses. However, some of these women could "inflect their diaries in unexpected directions and turn them into vehicles for genuine self-discovery" (Popkin 2009, 7-8), given that, "if anything, diaries evade authority" (Rak 2009, 19). This subversive potential of writing intimacy is analysed by Courtney Donovan and Pamela Moss who argue, after Foucault, that experiences of daily life can be subversive: "Access intimacy in feminist geography research is part of a wider political feminist project. Personal writing is effective at identifying, describing and contesting existing truth regimes that marginalize, oppress and exploit people, nonhuman beings and non-living things" (Donovan and Moss 2017, 14). While Buttimer's relationship with and commitment to feminism has been analysed by contributions drawing upon her own recollections and explicit claims (Ferretti 2019; Maddrell 2009), her diary shows the importance of personal writing for political and scholarly awareness and that of emotions and embodiments for building scholarly experiences.

In the first part of my paper, I discuss the state of the art of scholarship in neo and posthumanism, post-phenomenology, emotional geographies and feminist writing that can provide elements for linking humanistic and post-humanistic traditions. In the second part, I deal with Buttimer's 1965 journey to France, revealing the circumstances of her personal and material discovery of French scholarship and the places, events and affects that interacted with this process. In the third part, I discuss Buttimer's 1965 travel to Belgrade and Rome, revealing how her life circumstances affected her political and religious beliefs in subversive ways. In the fourth part, I discuss her 1966 scholarly Tour de France as the way in which her peculiar F. Ferretti, 2020: "Travelling in scholarly lifeworlds: new perspectives on (post)humanism, situated subjectivities and agency from a travel diary", Annals of the American Association of Geographers doi: 10.1080/24694452.2020.1715197 
scholarly lifeworld was produced through the interplay of circumstances, external agencies and a remarkable subjective intentionality.

\section{Rediscovering lifeworlds}

The field of "humanistic geographies", inspired by Buttimer, David Seamon (2018) and an heterogeneous array of geographers including Yi-Fu Tuan, David Ley, Edward Relph, Marwin Samuels and others, launched major challenges to the disciplinary hegemony of quantitative geography in the 1970s, addressing a plurality of themes later developed by cultural geographies and the "geo-humanities" (Adams, Hoelscher and Till 2001; Cresswell 2013; Smith 2009; Hawkins et al. 2015). Later, the phenomenological and existentialist philosophies upon which these approaches explicitly drew (Ley and Samuels 1978; Tuan 1976) fell mostly out of fashion, and new theories related to relational, non-representational and more-thanhuman approaches to geography questioned the role of the human subject (Anderson and Harrison 2010; Castree and Nash 2006; Thrift 2008), extending the traditional limits of human lifeworlds to "spaces of connectivity between more-than-human life worlds" (Whatmore 2002, 162). However, these approaches do not imply the complete disappearance of subjectivity, human freedom and agency, especially considering that humanism was not always and not necessarily anthropocentric, as demonstrated by recent scholarship on the anarchist geographical traditions (Ferretti 2018a).

This diary supports recent claims for rediscovering aspects of humanistic geographical traditions that are often underplayed in post-humanist and post-phenomenological scholarship. Drawing upon contributions by Henri Lefebvre (Simonsen 2005) and Maurice Merleau-Ponty, Kirsten Simonsen calls for walking "down the anti/posthumanist lane" (Simonsen 2012, 20)

F. Ferretti, 2020: "Travelling in scholarly lifeworlds: new perspectives on (post)humanism, situated subjectivities and agency from a travel diary", Annals of the American Association of Geographers doi: 10.1080/24694452.2020.1715197 
towards a "new humanism". Far from essentialism and Eurocentrism, this new humanism should take "seriously everyday embodied experiences, emotions and human agency ... not as an essential characteristic of the rational subject, but as contingent capacities for reflexivity, creative disclosure and transformation" (Simonsen 2012, 12, 15). Simonsen's subject is "simultaneously active and passive" (Simonsen 2012, 17) and ceaselessly open "toward the other (human or non-human)" (Simonsen 2012, 23), also due to the experiential nature of intersubjectivity. Yet, Simonsen's paper does not mention Buttimer's seminal article “Grasping the dynamism of lifeworld" (1976), where similar matters were discussed. Therefore, reappraising Buttimer's work appears necessary to complement these arguments. Buttimer's travel diary is an original and effective entrance to understanding the connection between ideas and experiences in the formation of her thinking and reveals how subjectivity emerges through relational and circumstantial processes.

This document can also be read after notions of non-representational subjects by John Wylie, who argues (following Nigel Thrift) for not entirely "dropping [out] the human subject" and for keeping "a certain minimal humanism" (Wylie 2010, 101). This implies that the subject is not simply "eliminated or re-asserted by non-representational approaches, rather it continues to haunt contemporary geographies in a way that is potentially creative and productive" (Wylie 2010, 101), deserving new consideration in non-representational scholarship. Although definitively decentred, subjectivities still play a role in understanding relational worlds, being constantly negotiated and reconstructed in non-representational terms. Scholars currently focus rather on the construction of subjects than on their coherent intentionality. For Wylie, "creative agency is only ever an effect, never a cause [beyond] conventional distinctions and demarcations of culture and nature, human and non-human" (Wylie 2010, 105). A similar F. Ferretti, 2020: "Travelling in scholarly lifeworlds: new perspectives on (post)humanism, situated subjectivities and agency from a travel diary", Annals of the American Association of Geographers doi: 10.1080/24694452.2020.1715197 
mediation between the absolute centrality of the subject and its complete dismissal is proposed by James Ash and Paul Simpson arguing for a "re-engagement with phenomenology through post-phenomenology" (Ash and Simpson 2016, 49). Although assuming a postphenomenological "move away from a subject-centred approach to experience" (Ash and Simpson 2016, 53), these scholars draw upon ideas of relational intersubjectivity, where subjectivities are constantly negotiated via a "perpetual process of subject formation" (Ash and Simpson 2016, 56). Following authors such as Gilles Deleuze, Emmanuel Levinas and JeanLuc Nancy, they argue that subjectivities are relationally shaped around "a co-appearance and disposition of self with self, self with other, and self with world" (Ash and Simpson 2016, 58). Paul Simpson defines this as the need for "spacing the subject", acknowledging its relational and mobile nature to match the recent "re-turn to phenomenological ideas amongst various geographers" (Simpson 2017, 5). Buttimer's travel notes are an exceptional source to deal with these notions.

Importantly, authors such as Wylie reinterpret former humanistic ideas on dwelling, arguing that notions of "being-in-the world" should draw upon mobility and displacement rather than fixity, considering that "displacement, and not rootedness, is originary" (Wylie 2012, 367) in the construction of the subject. In these displacements, sentiments and feelings constantly "shatter" and question human subjectivity (Simpson 2015), which is less shaped by its intentional agency than by its "passive" moments and its weaknesses. These can be considered as absences of the subject determined by its circumstances (Harrison 2008 and 2009), although their effects can be mediated by what Mitch Rose calls "dreams of presence", that is, subjects' willingness to be active (Rose 2006). In this vein, Buttimer's notes help disrupting critiques to humanistic geographies based on common understandings of their emphasis on dwelling as a F. Ferretti, 2020: "Travelling in scholarly lifeworlds: new perspectives on (post)humanism, situated subjectivities and agency from a travel diary", Annals of the American Association of Geographers doi: 10.1080/24694452.2020.1715197 
notion fixing identities and allegedly resulting in political and epistemological conservatism. Her mature works likewise contradict commonplace understandings of humanistic "being-inthe -world" as fixity in a place through her frequent references to her own mobility, and to inbecomingness as life condition rather than mere professional choice. The mobility of scholars in medieval studia, whom Buttimer defined as "border people" in her key work The Wake of Erasmus (1988), inspired the cosmopolitan, internationalist and multilingual programme that she developed in initiatives such as the International Dialogue Project and her commitment to the International Geographical Union (Ferretti 2019; Ferretti and Jones 2018).

In this paper, I refer to notions of "lifeworlds" and "circumstances", limited to the ways in which they can substantiate claims to bridge humanistic and post-humanistic traditions. Recently, Derek McCormack has acknowledged Buttimer among the first references for defining lifeworlds as a "phenomenological account of spacetime. ... characterised by a kind of metaphysics of presence based on the primacy of experience" (Mc Cormack 2016, 2). McCormack admits that "the emphasis in humanistic geography on the pre-, or more-than linguistic quality of life worlds experienced through the rhythms of embodiment seems to anticipate aspects of nonrepresentational theories" (McCormack 2016, 4). Therefore, it is possible to argue that current approaches do not dismiss humanistic claims to address the emotional and experiential space-times of individuals; rather, current research complicates such claims and integrates perspectives focused on subjects in their interactions with circumstances, which may include places and their materialities but also agency.

Thus, it is worth coming back to what Buttimer wrote about the "dynamism of lifeworld", considered as "the culturally defined spatiotemporal setting or horizon of everyday life.

F. Ferretti, 2020: "Travelling in scholarly lifeworlds: new perspectives on (post)humanism, situated subjectivities and agency from a travel diary", Annals of the American Association of Geographers doi: 10.1080/24694452.2020.1715197 
Scientific procedures which separate 'subjects' and 'objects', thought and action, people and environments are inadequate to investigate this lifeworld ... Humanization of the earth could be seen as a process in which mankind has sought various styles of dwelling in space and time" (Buttimer 1976, 277). Buttimer's definition of lifeworld could hardly be considered as logocentric, anthropocentric or devoid of a relational awareness, especially where Buttimer evoked notions of lifeworld as an "effort to bring intellectual knowledge into closer harmony with lived experience" (Buttimer 1976, 278), and "the notion of intersubjectivity" as part of a "focus on time-space rhythms [which] could add an important focus for investigating the concrete circumstances of everyday life, much of which lies beyond the potential discretion of human persons" (Buttimer 1976, 291). Buttimer eventually concluded by arguing for "transcend[ing] the artificial barriers which our Western intellectual heritage has placed between mind and being" (Buttimer 1976, 292). Therefore, it is possible to notice relevant elements of continuity between humanistic traditions as reinterpreted by Buttimer, current notions of "circumstances" and claims for embodied knowledge.

Following McCormack, I define circumstances as "the extrusion of the impersonal forces excessive of a life into the worldly textures and trajectories of that life" (McCormack 2016, 3) and as "structurings of influence on the capacities of diverse agencies to affect and be affected by other agencies" (McCormack 2016, 5). This does not deny the importance of subjective agencies, especially in the "processuality of worlding as something that shapes possibilities for acting, sensing and feeling" (McCormack 2016, 10). That is, the dynamism of lifeworlds still makes sense in relational and non-representational terms. This points again to the fact that a non-representational approach "is in no way an anti-human position” (McCormack 2003, 502).

F. Ferretti, 2020: "Travelling in scholarly lifeworlds: new perspectives on (post)humanism, situated subjectivities and agency from a travel diary", Annals of the American Association of Geographers doi: 10.1080/24694452.2020.1715197 
This can be also associated with the "emotional turn" experienced by geography from the early 2000s (Bondi, Davidson and Smith 2007; Davidson and Milligan 2004; Thrift 2004). The authors involved in this strand of research match classical views of humanistic geographers by arguing that geographical positivism has hindered approaches to emotions in the discipline. Therefore, "geography has tended to deny, avoid, suppress or downplay its emotional entanglements" (Bondi, Davidson and Smith 2007, 1). According to Owain Jones, emotional approaches challenge disembodiment pretentions for objectivity, confirming classical humanistic arguments on "the full humanness and complexity of being-in-the world" (Jones 2007, 207), a notion equally mobilised by Davidson and Milligan positing that emotions reveal "the very nature and experience of our being-in-the-world" (Davidson and Milligan 2004, 524). These authors claim for emotion as a precious resource for critical approaches to geography, considering that feelings cannot be dealt "like a stockbroker deals in dollars" (Bondi, Davidson and Smith 2007, 2). This argument by authors involved in the "emotional turn" in geography can match classical humanistic challenges to technocracy and knowledge's commodification, indirectly supporting Simonsen's claims for a new humanism conceived as "essentially relational ... formed in the intertwining of our 'own' bodily flesh with the flesh of the world" (Simonsen 2012, 18). This emphasis on emotions ad subjectivity largely matches Buttimer's agendas as discussed by recent scholarship (Ferretti and Jones 2018).

Finally, in the last two decades it has been widely repeated that there are no stable models of human identity and agency. Among others, Jamie Lorimer clarifies that this does not imply the end of the "human". "The human is now much less assured, much more caught within the play of forces and the discursive networks of other actants ... Posthumanism and humanism remain thoroughly interwoven" (Lorimer 2009, 353). This can be confirmed by works on emotional F. Ferretti, 2020: "Travelling in scholarly lifeworlds: new perspectives on (post)humanism, situated subjectivities and agency from a travel diary", Annals of the American Association of Geographers doi: 10.1080/24694452.2020.1715197 
geographies still taking insights from a "classical" existentialist like Jean-Paul Sartre (Smith, Davidson and Henderson 2012), and by authors such as Hayden Lorimer, who claims for the importance of "small stories" (Lorimer 2003). Recently, Lorimer drew upon Buttimer's definition of lifeworld as a "sense of place [that] can be derived from a cherished locale, to the point of deep emotional attachment, but it might also be the source of feelings of estrangement and alienation" (Lorimer 2018, 2). What follows shows how these notions originated from circumstantial encounters that Buttimer experienced in several places, especially in France, between 1965 and 1966.

\section{Travelling under circumstances}

"There is an extant letter written by the villagers to their curé asking him to pray that the glacier would not ruin them, to bid the ice retreat. ... You can still see the typical 'Valley Section': the three-tiered traditional exploitation (MAYEN, FORETT, ALPAGE) on the Swiss side, but not so clearly on the French side. We stood on the COL which divides Switzerland and France. This has been not only a physical divide (watersheds, etc.), but archaeological evidence also points to its role as a cultural divide" (DBA, Diary 1965-1966, 14 July 1965).

In one of her autobiographical texts, "Home-Reach-Journey", Buttimer refers to her experience as a young member of the Dominican order and a $\mathrm{PhD}$ student in Seattle, pointing first to some non-conformism that characterised her interests, namely, in social geography, a notion which was viewed with a certain suspicion at that time, also being inspired by French-speaking authors who were almost completely unknown in the United States. This often led her to F. Ferretti, 2020: "Travelling in scholarly lifeworlds: new perspectives on (post)humanism, situated subjectivities and agency from a travel diary", Annals of the American Association of Geographers doi: 10.1080/24694452.2020.1715197 
burning “midnight oil” (Buttimer 2001, 24), reading authors of her interest beyond what was arguably requested by her institutions (both religious and educational).

The archival document that I analyse is structured as something between a personal diary and a picture album. Pictures, postcards and original documents are often stuck to the diary pages, partially matching Lejeune's definition of collage-diary or "herbarium" (Lejeune 2009 40), where objects are attached to keep a stronger emotional record of the events. Typewriting suggests that this text was re-transcribed from Buttimer's handwritten notes to remain as a souvenir for her, but, at the same time, the author tried to reproduce the original writing style accounting for emotions, for instance through the heavy use of suspension points and exclamation or interrogation marks. While highlighting the importance of keeping a record of experience, which was paramount in Buttimer's personal and scholarly formation, this document also matches ideas discussed above of immediate writing as a practice challenging representational divides between theory and praxis. Moreover, it shows how emotions, experiences and affective/affecting circumstances are fundamental in understanding the formation of scholars' careers and ideas, as confirmed by the strong link that Buttimer maintained with French geography and Francophonie until her late days (Clout 2017).

From the beginning, Buttimer's travel diary is profoundly marked by emotions and feelings. The literary construction of the piece is apparent from its first page, starting with the formulation: "It all began ...", referring to the moment in which Buttimer, at the completion of her PhD, was encouraged to apply for a postdoctoral fellowship in Belgium for the 1965-1966 academic year. Describing the moment when her advisor came to ask her: "Got any interest in

F. Ferretti, 2020: "Travelling in scholarly lifeworlds: new perspectives on (post)humanism, situated subjectivities and agency from a travel diary", Annals of the American Association of Geographers doi: 10.1080/24694452.2020.1715197 
Belgium, Sister?", ${ }^{1}$ the subject of the narration appears emotionally upset by the events and by complex conditions external to her subjective will, such as the authorisation that Buttimer needed from the Dominican order to begin this international process. The successful outcome of the entire process, marked by the reception of an official letter of invitation, was highlighted in the diary as an emotional event. "On the Feast of Saint Thomas, March 7, 1965, Sister Mary Anthony slipped this letter under my door. Assumption Convent never looked so beautiful!".2 A picture of the convent and the original letter are enclosed in this page of the diary. These few lines expose an ambivalence which accompanied Buttimer for her trip and for a large part of her career. On the one hand, she always claimed her Catholic faith and identity; on the other, she always showed a curiosity and a taste for travels, life experiences, and intellectual and personal freedom that clashed with monastic constraints. For Buttimer, the convent never looked so beautiful as in the moment of leaving.

Strong emotions also accompanied the reception of another international invitation for the same summer, which led to the second of the three listed journeys. An entire page of the diary is occupied by the following sentence, all in uppercase characters. "And on May 20, wonder of wonders, an invitation to the Belgrade World Population Conference". ${ }^{3}$ Born to a farming family from County Cork and a later immigrant to Seattle, Buttimer found the possibility of travelling across Europe and personally experiencing the Francophone world as an exceptional opportunity. She felt that it would be a turning point in her life, and indeed it was. As a quick look at her biography can show (Buttimer 2016; Ferretti and Jones 2018), from that moment

\footnotetext{
${ }^{1}$ University College Dublin, School of Geography, Anne Buttimer's Archives, Box 102 of the provisional arrangement (hereafter DBA), Diary 1965-1966, November 1964.

${ }^{2}$ DBA, Diary 1965-1966, 7 March 1965.

${ }^{3}$ DBA, Diary 1965-1966, 20 May 1965.

F. Ferretti, 2020: "Travelling in scholarly lifeworlds: new perspectives on (post)humanism, situated subjectivities and agency from a travel diary", Annals of the American Association of Geographers doi: 10.1080/24694452.2020.1715197
} 
onwards, nobody and nothing could have stopped Buttimer's international and cosmopolitan mobility or her global networking.

To prepare for her trip to the Belgrade World Population Conference in September 1965 and her subsequent year in Louvain, Buttimer took advantage of the summer holidays to organise a first sojourn to France after a stop at home in Ireland. Again, her landing at Shannon Airport is depicted in the most emotional terms: "Halleluiah! It was the most wonderful thing to see the green 'quilted' landscape, the smallness and familiarity of everything, the unconcerned, relaxed and peaceful setting ... Lord, it is good to be home". ${ }^{4}$ On her trip to Paris, Anne was accompanied by one of her aunts, Nora, and by a friend called Una. This company looked something like parental control and chaperonage, given that most of the programmes for this official holiday were indeed designed for Anne's professional meetings, though she always looked happy with her travel companions.

After arriving in Paris, Anne contacted Jacqueline Beaujeu-Garnier (1917-1995), who would be her first mentor in France and a life-long friend, as witnessed by the correspondence that they exchanged ${ }^{5}$ and by Beaujeu-Garnier's participation in Buttimer and Hägerstrand's International Dialogue Project as one of the first interviewees. ${ }^{6}$ In her 1981 interview with Buttimer, Beaujeu-Garnier explicitly addressed the need for academics to exit the "ivory tower", confirming the important role that she played in the renovation of French geography and in its opening to societal issues. The originality of Beaujeu-Garnier's commitment is

\footnotetext{
${ }^{4}$ DBA, Diary 1965-1966, 20 June 1965.

${ }^{5}$ DBA, Buttimer correspondence, Folder France.

${ }^{6}$ International Dialogue Project, G21, https://www.youtube.com/watch?v=oB-kn14u4Ac\&feature=youtu.be

F. Ferretti, 2020: "Travelling in scholarly lifeworlds: new perspectives on (post)humanism, situated subjectivities and agency from a travel diary", Annals of the American Association of Geographers doi: 10.1080/24694452.2020.1715197
} 
especially apparent if we consider the specific tradition of French geography in the twentieth century, a field which was mostly characterised by the rejection of explicit political engagement and epistemological discussion (Orain 2009). Like Buttimer, Beaujeu-Garnier was very active in international networking and is still a very popular figure in countries like Brazil thanks to her acquaintance with Brazilian critical geographers such as Milton Santos and Manuel Correia de Andrade (Ferretti 2018b).

Buttimer's diary reveals the emotions that she experienced while waiting for her first meeting with this senior academic figure, including some anxiety on the possible reception of an IrishAmerican nun in secular France. "Phoned Madame Beaujeu: she is busy and rushing to a meeting, but says 'come at $6.00 \mathrm{pm}$... I am going to Mass ...' She's Catholic D[eo] G[ratias]”. 7 This comforting revelation was inserted in the context of a new (corpo)reality where Buttimer hesitated between wearing Dominican or secular dresses to make her new interlocutors comfortable and to facilitate interaction. "All during the day I was in civvies, but changed back for evening visit to madame Beaujeu". ${ }^{8}$ That evening, despite being a Catholic, Beaujeu looked surprised at her guest's attire: "Why did you change to come to see me?". 9 All along these travels, this Dominican dress can be considered a material and bodily circumstance acting both as an element of empathy and as an element of wariness and suspicion, playing a non-secondary relational role in the big dilemma mentioned above. Buttimer's displayed identity as a Dominican sister could alienate some interlocutors, but, at the same time, it could gain the sympathy of some of them. Moreover, several parts of the diary show how she relied on

\footnotetext{
${ }^{7}$ DBA, Diary 1965-1966, 25 June 1965.

${ }^{8}$ DBA, Diary 1965-1966, 25 June 1965.

${ }^{9}$ DBA, Diary 1965-1966, 25 June 1965.

F. Ferretti, 2020: "Travelling in scholarly lifeworlds: new perspectives on (post)humanism, situated subjectivities and agency from a travel diary", Annals of the American Association of Geographers doi: 10.1080/24694452.2020.1715197
} 
convents and transnational Catholic networks to find accommodation and material support during these journeys. ${ }^{10}$

After meeting Beaujeu-Garnier, Buttimer travelled to Strasbourg, where she started her systematic pursuit of geographers whose works and opinions she deemed useful for her research. A feature characterising the affective side of these circumstances was her ceaseless mobility, often subject to external agencies: these meetings were generally organised with short notice and arranged by phone. The young geographer showed a great adaptability in physically going to see persons, departments and cities, interacting at each time with sets of circumstances which were not defined by intellectual exchange alone but also by the emotional and contingent aspects of each encounter. These might range from hope and excitement to tiredness and disillusionment and were often affected by the causality of events such as postal errors or missed appointments. This is an example of the complex interactions that build the relation between the subject and the world, constantly displacing and renegotiating subjective and external agencies (Wylie 2012).

Buttimer's first interactions in Strasbourg were not easy. First, at the hotel, the "French receptionist was aghast when she discovered I was a Religious". ${ }^{11}$ Then, when walking at the University the day before her meeting with a leading figure of French rural and regional geography, Etienne Juillard (1914-2006), she gathered disquieting information about her next host. "One [student] took geography from Juillard. So, I had the inside story from her ... he is Protestant, and somewhat anti-Catholic. He thinks religious are anachronisms ... ERGO ...

\footnotetext{
${ }^{10}$ DBA, Diary 1965-1966, 26 June 1965.

${ }^{11}$ DBA, Diary 1965-1966, 29 June 1965.
}

F. Ferretti, 2020: "Travelling in scholarly lifeworlds: new perspectives on (post)humanism, situated subjectivities and agency from a travel diary", Annals of the American Association of Geographers doi: 10.1080/24694452.2020.1715197 
wear your civvies girl!". ${ }^{12}$ Again, this reveals the deep circumstantial ambivalence which rendered these experiences so emotional: Buttimer was an intellectual and an exponent of the severe Dominican Order, but she was at the same time a young person, thirsty for life experiences possibly done in "civvies" and outside the walls of religious or secular convents. However, during the lunch to which she was invited at Juillard's home, the main challenge for Buttimer was not theological, but epistemological. According to Buttimer, Juillard "was nervous, ill at ease and obviously not willing to spend time on such unpragmatic topics as ... social geography". ${ }^{13}$ In the afternoon, the French geographer took his Irish guest to the department, when they met other geographers whose talk showed how the idea prevailing in Strasbourg was that social geography was not a subdiscipline but rather a standpoint. At that time, this meant diminishing the importance of Buttimer's work, leading to her final disheartened commentaries that: "It is true that French geographers do not like to discuss methodology too much". ${ }^{14}$ However, young Buttimer was encouraged by discovering that Juilliard was a supporter of "women scholars". ${ }^{15}$ This reveals, first, that another big challenge Buttimer had to face was related to gender biases and masculinism in the discipline and, second, that gender issues were played in rather discrete ways in Buttimer's works but were far from absent from her views as noticed above.

Buttimer next went to Metz, in the Lorraine region, where she could take "a well-documented urban field trip" $" 16$ led by François Reitel, a rather obscure figure in French geography but one who led Buttimer to discover a French phenomenon which played a role in her analyses of

\footnotetext{
${ }^{12}$ DBA, Diary 1965-1966, 29 June 1965.

${ }^{13}$ DBA, Diary 1965-1966, 30 June 1965.

${ }^{14}$ DBA, Diary 1965-1966, 30 June 1965.

${ }^{15}$ DBA, Diary 1965-1966, 30 June 1965.

${ }^{16}$ DBA, Diary 1965-1966, 2 July 1965.
}

F. Ferretti, 2020: "Travelling in scholarly lifeworlds: new perspectives on (post)humanism, situated subjectivities and agency from a travel diary", Annals of the American Association of Geographers doi: 10.1080/24694452.2020.1715197 
social marginalized spaces (Buttimer 1969): the banlieues. "The population is quite young: many commute to the steel industry plants of neighbouring towns. Many immigrants ... occupy some of the dingiest quartiers I've ever seen ... major job!". ${ }^{17}$ These remarks expose how the idea of doing scholarly research for social aims was deeply embedded in Buttimer's views, as she always declared (Buttimer 1974).

One of the main suggestions that Buttimer received from Juillard was that she went to Munich to see social geographer Wolfgang Hartke (1908-1997), a German familiar with French language and scholarship. Hartke remained Buttimer's friend and correspondent, being one of the first interviewees for the International Dialogue Project. ${ }^{18}$ Not coincidentally, it was outside France that Buttimer found the first declared fan of social geography and of her work. "Hartke explained why social geography had excelled in Holland and Germany: no sociology worth speaking about! ... He would like me to return for at least three months some time. His approach is quite revolutionary in German geography. No training in mathematics, he appreciates their role in problem-solving, especially when actual patterns seem to contradict the 'rational' pattern". ${ }^{19}$ The humour and even satisfaction with which Buttimer recounted her conversation with Hartke exposes the importance of meeting these people for Buttimer's future challenges to technocracy and the quantitative hegemony over geography. These circumstances strengthened her willingness to go ahead with what she had in mind: performing social and engaged scholarship, which would be later considered "humanistic" geographies exploring "lifeworlds".

\footnotetext{
${ }^{17}$ DBA, Diary 1965-1966, 2 July 1965.

${ }^{18}$ International Dialogue Project, G01 https://www.youtube.com/watch?v=BQWD2TJ7 jA\& \&eature=youtu.be

${ }^{19}$ DBA, Diary 1965-1966, 6 July 1965.
}

F. Ferretti, 2020: "Travelling in scholarly lifeworlds: new perspectives on (post)humanism, situated subjectivities and agency from a travel diary", Annals of the American Association of Geographers doi: 10.1080/24694452.2020.1715197 
Coming to Grenoble from the Swiss Alps, Buttimer met geographers Paul Veyret (1912-1988) and Germaine Veyret-Verner (1913-1973). ${ }^{20}$ On Bastille Day, the French couple took Buttimer on an Alpine trip to the watershed between France and Switzerland, which stimulated again her social geographical imagination, including the implicit reference to Patrick Geddes's valley section contained in the epigraph above, where Buttimer's thirst for Francophone geographies and cultures could not be displayed more clearly. Descending the Rhone Valley through Lyon and Avignon was an occasion for Buttimer to evoke her readings of French poetry, wondering about Alphonse de Lamartine and expressing her deep fascination for the view of "the Rhone in all her splendour" and for her own "first glimpse at the Mediterranean: a hazy blue, flat and satin". ${ }^{21}$ Her first destination was eventually Carcassonne, a classical tourist place, documented in the diary by a number of pictures; a later stop was Lourdes, where Buttimer clearly expressed an important feature or her religious faith. That is, her intellectual approach to Catholicism rendered her ostensibly wary and slightly disdainful of expressions of popular worship associated with saints and miracles, as revealed by her humorous remarks on the crowds that she encountered. "A regiment of Italians took over and I left ... Too bad these old ladies have to trample everyone else down on their adamant pilgrimage to save their souls". ${ }^{22}$ Even though Buttimer wrote from a clear position of privilege as an intellectual and as a person who could afford this kind of journeys, it is possible to argue that also Dominican transnationalism played a key role as a circumstance shaping her intellectual lifeworlds, often in conflict with other experiences and on some extent even with the subject's will, as I explain below.

\footnotetext{
${ }^{20}$ DBA, Diary 1965-1966, 14 July 1965.

${ }^{21}$ DBA, Diary 1965-1966, 15 July 1965.

${ }^{22}$ DBA, Diary 1965-1966, 17 July 1965.
}

F. Ferretti, 2020: "Travelling in scholarly lifeworlds: new perspectives on (post)humanism, situated subjectivities and agency from a travel diary", Annals of the American Association of Geographers doi: 10.1080/24694452.2020.1715197 
Traveling to Utrecht few days later, Buttimer saw Christian Van Paassen (1917-1996), the author of a history of "classical" geography, who was another supporter of social geography. After her conversation with Hartke in Munich, this was paradoxically the meeting that affected Buttimer most emotionally and intellectually, though they both occurred outside France. "Van Paassen is quite exciting: we chatted all afternoon about Vidal de la Blache, social geography and many things ... Thank God and the Holy Spirit: this chat has given me many insights". ${ }^{23}$ Indeed, Buttimer took the greatest advantage from these conversations, spending her following day in Amsterdam "[writing up] Van Paassen's notes"24 and, in the following month in Cork, spending "nearly every day reading, digesting and evaluating" 25 the materials for the following trip to Belgrade.

The emotions about the discovery of new social and scholarly worlds by the young author of this diary are expressed through embodied experiences and affecting encounters. It is possible to suppose that these mundane circumstances opened an emotional and intellectual creep between Buttimer's religious vocation and the multifaceted complexity of the worlds that she started experiencing in the international geographical milieus, allowing her to build her own world, starting from intimate writing. Buttimer started wondering whether this new world was compatible with the beliefs of those who had supported her vocation. "I am beginning to realise what a Religious vocation means to members of my family, and how disgracefully short I fall of the mark. The Sisters write so often! They are so interested in what I'm doing ... God bless

\footnotetext{
${ }^{23}$ DBA, Diary 1965-1966, 21 July 1965.

${ }^{24}$ DBA, Diary 1965-1966, 22 July 1965.

${ }^{25}$ DBA, Diary $1965-1966$, July $23^{\text {rd }}-$ August $30^{\text {th }} 1965$.
}

F. Ferretti, 2020: "Travelling in scholarly lifeworlds: new perspectives on (post)humanism, situated subjectivities and agency from a travel diary", Annals of the American Association of Geographers doi: 10.1080/24694452.2020.1715197 
them! There is a strange unity now between ... my natural and religious families: they both are the immediate framework within which God communicate His love to me" ${ }^{26}$ Or was it a need for control, to prevent possible dissidence? Buttimer's brilliant international scholarly career went well beyond what her "religious family" originally designated for her, showing how circumstances can challenge plans from any formal or informal authority. But until that moment, feelings like "love", often mentioned, played a mediating role in the negotiations between the subject and the contrasting and shattering worlds - scholarship, family and religion, in which her subjectivity was being built (Wylie 2009).

\section{From Belgrade to Rome: politics, religion and subjectivities}

"We have all kinds of damps here. On one hand there is an army of abstruse scholarly types: economists and demographers who have made an exhaustive inventory of population facts, and resources facts ... but have not bothered to draft a synthetic picture for the layman... On the other hand, you have the therapists: zealous apostles of birth control, mainly coming from the IPPF and the American contingent. Their Faith in this position is amazing. Then you have the Catholic contingent: conservative and re-actionary ... And finally, the Marxists ... insisting on the Marxist solution, the social control of the means of production"

(DBA, Diary 1965-1966, 1 September 1965).

As anticipated above, Buttimer was incredibly proud of receiving a personal invitation to the World Population Conference in Belgrade from 30 August to 10 September 1965. Her

\footnotetext{
${ }^{26}$ DBA, Diary $1965-1966$, July $23^{\text {rd }}-$ August $30^{\text {th }} 1965$.
}

F. Ferretti, 2020: "Travelling in scholarly lifeworlds: new perspectives on (post)humanism, situated subjectivities and agency from a travel diary", Annals of the American Association of Geographers doi: 10.1080/24694452.2020.1715197 
certificate of attendance was displayed like a relic at the beginning of the related chapter of the diary. The travel organisation still involved a chaperon to accompany Anne, in this case one "Auntie Mary", who was registered to the conference in the "ladies' program". 27 This was an awfully sexist way to entertain accompanying wives, taking for granted that the delegate was a man, and was also typical at the meetings of the IGU at that time. This conference was also one of the occasions at which Buttimer explicitly complained about "a horrible ... male dominance". ${ }^{28}$ Intimate writing was the place where Buttimer could put on page issues that it would have been difficult to express publicly form her position at that time, such as gender discomfort.

According to Buttimer, when she entered the room, people at "registration desk [were] somewhat stunned when I said I was a delegate". ${ }^{29}$ While it is not clear if this was due to the delegate's gender, age or possible religious dress, what is certain is that Buttimer's sarcasm about the groups of delegates that she met reveals that her emotions about attending this conference did not diminish her critical and prickly attitudes, as apparent in her statement reproduced in the epigraph for this section. Relatively deceived by formal conference sessions, Buttimer revealed her social attitudes by taking advantage of networking, first chatting with some ecclesiastics, including those from the "Third World", the most difficult to meet for her at that moment. This included one "Father Betancur from Bogota, Colombia [We spoke] on the role of sisters in Latin America". ${ }^{30}$

\footnotetext{
${ }^{27}$ DBA, Diary 1965-1966, 1 September 1965.

${ }^{28}$ DBA, Diary 1965-1966, 8 September 1965.

${ }^{29}$ DBA, Diary 1965-1966, 1 September 1965.

${ }^{30}$ DBA, Diary 1965-1966, 2 September 1965.
}

F. Ferretti, 2020: "Travelling in scholarly lifeworlds: new perspectives on (post)humanism, situated subjectivities and agency from a travel diary", Annals of the American Association of Geographers doi: 10.1080/24694452.2020.1715197 
Two months earlier, when at Lyon, Buttimer had missed French geographer Renée Rochefort (1924-2012), a pioneer of French social geography, who later became her friend and correspondent. ${ }^{31}$ As Rochefort was also attending the conference, this was an occasion for Buttimer to have a meeting which again acquainted her with aspects other than mere rationality, reviving her enthusiasm. "I at last met Renée, and we had lunch together. She is most gracious, gave me many ill-sorted ideas and 'attitudes' about social geography". ${ }^{32}$ The two women took an excursion on the Danube the day after, and attended other walks and receptions together during the conference. ${ }^{33}$

However, despite her initial enthusiasm, Buttimer seemed to be more interested in discovering Yugoslavian societies rather than attending the conference sessions; she was especially curious about the conditions of religious people. To that end, she visited parishes and talked to priests and nuns she sometimes met randomly in the street. To Buttimer, "Youth is getting tired of the Party programs, and they are looking for something new". ${ }^{44}$ However, she realised that Tito's regime was no joke when noticing that, at Sunday Mass, "two spies were present". ${ }^{35}$ The following step of this journey was a very different place in its religious meaning: Rome, the city of the Pope, where Buttimer's mother joined the group.

Like in the case of Lourdes, some disillusionment followed the initial expectation: Buttimer did not appreciate the mundane commodification of faith that was widely showcased in the Italian capital. "People are so cold and strange ... First impressions of Rome are terribly

\footnotetext{
${ }^{31}$ DBA, Buttimer correspondence, Folder France.

${ }^{32}$ DBA, Diary 1965-1966, 2 September 1965.

${ }^{33}$ DBA, Diary 1965-1966, 9 September 1965.

${ }^{34}$ DBA, Diary 1965-1966, 5 September 1965.

${ }^{35}$ DBA, Diary 1965-1966, 5 September 1965.
}

F. Ferretti, 2020: "Travelling in scholarly lifeworlds: new perspectives on (post)humanism, situated subjectivities and agency from a travel diary", Annals of the American Association of Geographers doi: 10.1080/24694452.2020.1715197 
disillusioning. Rough, noisy, bustling and really have a commercial eye: they 'smell' the dollar and fleece you". ${ }^{36}$ This discomfort appeared during a discourse of the Pope (at that moment Paul VI): "Claustrophobia almost everywhere ... I wish and pray that Rome, the Vatican, the ceremonies could move me.... if only I could appreciate this wonderful privilege, but I'm dead to it; immune, unresponsive. Why? Is Rome, its art, its institutions and customs just a RELIC? Why this awful repugnance I feel? After longing for this all my life, here it is and I cannot enjoy it". ${ }^{37}$ This physical and psychological discomfort was part of the dilemmas and ambivalences raised above, and might exemplify what Mitch Rose defines "sacredness" as a good example of pre-subjective perception belonging to the complex ways in which subjectivities are negotiated in constructing an I-ness which is never already predetermined (Rose 2010).

In the following academic year, 1965-1966, Buttimer was a postdoctoral research fellow in Louvain, from where she could easily journey to France. Her trip in March 1966 was first organised to attend the Journées géographiques, which gathered most French geographers in Caen (Normandy). It turned out to be a real Tour de France where Buttimer discovered different ways of doing geography, by meeting almost daily French social or socially engaged geographers. At each time, this implied the creation of new relationships in new places with all the charge of emotions and circumstances which contributed to build a peculiar scholarly career.

\section{A geographer's Tour de France}

\footnotetext{
${ }^{36}$ DBA, Diary 1965-1966, 10 September 1965.

${ }^{37}$ DBA, Diary 1965-1966, 14 September 1965.
}

F. Ferretti, 2020: "Travelling in scholarly lifeworlds: new perspectives on (post)humanism, situated subjectivities and agency from a travel diary", Annals of the American Association of Geographers doi: 10.1080/24694452.2020.1715197 
"Then came a phone call from an Icelandic student who had made a dramatic discovery about the Vikings and wanted to chat about it with Renée [Rochefort]. She called me in to listen to him, and it seemed he was almost crazy: Poor boy, the standardizing influence of Lyon University is stifling for him. She drove me home very late, my eyes are burning sore, and the room is cold and stare. Students all around, seem nice enough: I'm just a passing student too" (DBA, Diary 1965-1966, 10 March 1966).

In a review of the Caen conference that she wrote for Professional Geographer, Buttimer gave the first insights on the philosophy which informed her $\mathrm{PhD}$ thesis (Buttimer 1971) on the social aspects of the "classical" French School of Geography, arguing that these trips aimed to foster transcultural communication between French and North American traditions, challenging "monolingualism on both sides" (Buttimer 1968, 92). The paper's discussion immediately shifted from the rational to the emotional, highlighting how attending this conference was "a memorable event in the life of an American geographer" (Buttimer 1968, 92). Buttimer also observed how scholarly work in France, although heterogeneous, was slowly departing from its traditional regionalist frameworks to address "underdevelopment, population distribution, hunger and nutrition ... topics such as voting behaviour, tourism, energy" in what "could be described as a quest for relevancy" (Buttimer 1968, 95). The impact of this experience was so strong for Buttimer that her 1969 paper on "social space", following her fieldwork in working-class neighbourhoods in Glasgow, discussed issues raised by French authors and confirmed her attraction to the nonconformists. This was the case with social geographer Max Sorre (1880-1962) and "social" architect Chombart de Lauwe (1913-1998), both presented as "prophets unacceptable in their own country" (Buttimer 1969, 418). This F. Ferretti, 2020: "Travelling in scholarly lifeworlds: new perspectives on (post)humanism, situated subjectivities and agency from a travel diary", Annals of the American Association of Geographers doi: 10.1080/24694452.2020.1715197 
unorthodoxy was related to these authors' willingness to force and disrupt the disciplinary paradigms of their respective consolidated fields, as Anne would go on to do in Anglophone geography in the following decade. This also connects with other parts of Buttimer's archives, eventually her correspondence with Anglophone and Francophone geographers in the context of her global networking for the International Dialogue Project and the IGU, which has been explored by recent scholarship (Ferretti 2019).

At the Caen conference, Buttimer was once again mentored by Beaujeu-Garnier, who introduced her "to a whole gang of French geographers: Dresch, Journaux, Guilcher, Verrière (demographic interest in Ireland), Lecomte, Derruau, and the Lyon crowd. The dinner was sumptuous, and afterwards, Mlle. Lefèvre got me in touch with the Liège crowd". ${ }^{38}$ That time, Buttimer came directly from Louvain and was not accompanied by members of her family. Beaujeu-Garnier was something like a family figure who led Buttimer on a discovery pathway that the diary's author narrated again with emotional tones. "Jacqueline is really a favourite among her colleagues and no wonder: she is charming, dynamic, kind and clever. This pace is a bit hectic, though, and the hotel is so luxurious". ${ }^{39}$ Affects and emotions could not be separated from the geographer's intellectual experience.

At the meeting, Buttimer dealt with a topic on which her social inspiration found some contact points with French approaches to regionalisation: the "Third World", which was especially addressed by socially committed geographers such as Jean Dresch (1905-1994) and Yves Lacoste. Despite being a physical geographer, Dresch was an important figure in anti-

\footnotetext{
${ }^{38}$ DBA, Diary 1965-1966, 5 March 1966.

${ }^{39}$ DBA, Diary 1965-1966, 5 March 1966.
}

F. Ferretti, 2020: "Travelling in scholarly lifeworlds: new perspectives on (post)humanism, situated subjectivities and agency from a travel diary", Annals of the American Association of Geographers doi: 10.1080/24694452.2020.1715197 
colonialism and was involved in Moroccan decolonisation (Dresch 1979). "Symposium on Les pays sous-developpés at which Dresch presided. Several contributions from Lacoste, Rochefort, Monbeig, Pelletier, Delvert, and many others". ${ }^{40}$ This session was very revealing in the political, epistemological and generational conflicts ongoing in France. On the one hand, there were politically engaged geographers such as Dresch and Lacoste, and on the other were scholars of Southeast Asia such as Jean Delvert (1921-2005), who "adamantly insist[ed] that the geographer's job is to present the 'peasant genre de vie' and no strings attached: it's not his job to recommend this policy or that". ${ }^{41}$ This endorsement of "disengaged" and "irrelevant" geography clearly clashed with Buttimer's views; she also reported with some fun another oldfashioned remark by Hildebert Isnard (1904-1983), suggesting that, in the so-called traditional ways of life in the Third World, 'the peasant (passive) attitude is quite 'sympathique' why change??? Often, we find a perfectly functioning social system coinciding with an 'underdeveloped' economy". ${ }^{42}$ However, this mix of colonialism and paternalism did not prevent Buttimer from enjoying the numerous meetings and acquaintances that she was gaining, including leading figures of the renovation of French geography such as Roger Brunet.

The second day started with a session "on Géographie agraire, presided over by $\mathrm{P}$ [ierre] Flatrès. Sat next to Michel Philipponneau, who was rather alarmed at who I was". ${ }^{43}$ Though seemingly uncomfortable in sitting beside a nun, Michel Philipponneau (1921-2008) became one of Anne's French friends. A professor at Rennes and one of the few publicly declared socialists in geography, Philipponneau was the French mentor of critical Latin American

\footnotetext{
${ }^{40}$ DBA, Diary 1965-1966, 6 March 1966.

${ }^{41}$ DBA, Diary 1965-1966, 6 March 1966.

${ }^{42}$ DBA, Diary 1965-1966, 6 March 1966.

${ }^{43}$ DBA, Diary 1965-1966, 7 March 1966.
}

F. Ferretti, 2020: "Travelling in scholarly lifeworlds: new perspectives on (post)humanism, situated subjectivities and agency from a travel diary", Annals of the American Association of Geographers doi: 10.1080/24694452.2020.1715197 
geographers such as Manuel Correia de Andrade (Ferretti 2018b) and Angel Bassols Batalla (Delgadillo 2015). That same day, Buttimer was introduced to "Le Coz (Montpellier) and to Paul Claval", receiving invitations "to Besançon and ... to Lyon and Montpellier", while Veyret "insisted that I also stop at the [Grenoble] Institut de Géographie Alpine". ${ }^{44}$ The day after, Buttimer "met Guy Lasserre and the Bordeaux crowd". ${ }^{45}$ Another geographer interested in Third World issues, Guy Lasserre (1920-2001) was likewise one of the mentors of de Andrade and of Milton Santos. This latter was working in France at that moment, although there is no evidence that Buttimer met the Brazilian geographer at this stage, and it is more likely that they met in the United States in the 1970s (Ferretti 2019). However, meeting Lasserre was an instrumental moment in organising Buttimer's subsequent Tour de France.

This Tour de France started immediately after the end of the conference and was presented in Buttimer's diary with pilgrimage-like tones. The first step was "the great Sorbonne" in Paris, although something like disillusion characterised this visit, as the great prestigious French university looked like "a dreary spot. Very little going on, and the profs most inaccessible". ${ }^{4}$ Therefore, Buttimer made the first of a series of visits to Mariel Jean-Brunhes Delamarre (1905-2001), daughter and curator of the archives of Jean Brunhes (1869-1930) who was, together with Sorre and Pierre Deffontaines (1894-1978), one of the exponents of French geographical traditions in whose works Buttimer found a direct inspiration. Unlike most of the "post-Vidalians", Brunhes and Deffontaines had both a strong interest in social geography,

\footnotetext{
${ }^{44}$ DBA, Diary 1965-1966, 7 March 1966.

${ }^{45}$ DBA, Diary 1965-1966, 8 March 1966.

${ }^{46}$ DBA, Diary 1965-1966, 9 March 1966.
}

F. Ferretti, 2020: "Travelling in scholarly lifeworlds: new perspectives on (post)humanism, situated subjectivities and agency from a travel diary", Annals of the American Association of Geographers doi: 10.1080/24694452.2020.1715197 
which was eventually coupled with engagement in social Catholicism (Robic, Tissier and Pinchemel 2011).

In Lyon, Buttimer again met with Renée Rochefort and her family, revealing a reason for their affinity: "Her parents are charming, Catholic and simple folk" ${ }^{47}$ Beyond Catholicism, it is possible to hypothesise that Buttimer and Rochefort had a certain complicity between outsiders in the academy. They both came from non-academic families, which was accordingly comprised among the circumstances affecting Buttimer's professional and political lifeworld, though it is not always easy to trace the social origins of her acquaintances: for sure, she was always attracted to unorthodox and non-conformist scholars. The epigraph at the top of this session, related to Buttimer feeling of being only "a passing student" during her visit to Rochefort, highlights the effects of mobilities on a subject who often feels disoriented and lost before circumstances, being shaped progressively by complex relational experiences and feelings.

In Grenoble, Buttimer wrote that she missed travelling with her relatives and friends. "The Veyrets have reserved a room for me at Hotel Terminus. ... This is luxury indeed, but oh, so lonely". ${ }^{48}$ Even though very different from Yugoslavia, French society presented a relatively high level of secularization, very different from the Irish and North American contexts more familiar to Buttimer, who was intrigued by her discussions with local ecclesiastics. "This is a leftist society: old-fashioned, introverted curates". ${ }^{49}$ After further excursions in the Alps and

\footnotetext{
${ }^{47}$ DBA, Diary 1965-1966, 10 March 1966.

${ }^{48}$ DBA, Diary 1965-1966, 13 March 1966.

${ }^{49}$ DBA, Diary 1965-1966, 14 March 1966.
}

F. Ferretti, 2020: "Travelling in scholarly lifeworlds: new perspectives on (post)humanism, situated subjectivities and agency from a travel diary", Annals of the American Association of Geographers doi: 10.1080/24694452.2020.1715197 
the Rhone Valley, Buttimer visited the old university town of Montpellier, where she was welcomed by her recent acquaintance Jean Le Coz (1920-1991), another leftist geographer who was an acknowledged supporter of Moroccan independence together with Dresch (El Gharbaoui 1978). Le Coz made a strong impression on Buttimer. "He's a grand old chap, exMoroccan, who gave me much of the inside story about French geography departments, how guys get elected, etc.". ${ }^{50}$ Among the local geographers to whom Buttimer was introduced, Raymond Dugrand (1925-2017) especially interested Buttimer with his works on urban geography. A Marxist, Dugrand was "a follower of Chombart de Lauwe, Dresch, and George". ${ }^{51}$ Pierre George (1909-2006), a member of the French Communist Party, was the supervisor of many of the critical and anti-colonialist geographers of Lacoste's generation (Bataillon 2006), and the inclusion on this list of a "heretic" like Chombart meant that Buttimer had found another supporter of socially engaged geography. It was in this human environment that Buttimer wished to spend her scholarly life. Meanwhile, she enjoyed a Mediterranean excursion to the Camargue and the town of Sète, which gave birth to one of her favourite French poets, Paul Valéry. ${ }^{52}$

The next step of Buttimer's Tour de France was Toulouse, the capital of the southwest and another region with strong leftist traditions, where she was received by Bernard Kayser (19262002). Another French reference to Brazilian critical geographers and a scholar of rural geography akin to social approaches, Kayser remained Buttimer's correspondent. ${ }^{53}$ Afterwards, Buttimer went to Bordeaux, where she met Lasserre and the dean Louis Papy

\footnotetext{
${ }^{50}$ DBA, Diary 1965-1966, 16 March 1966

${ }^{51}$ DBA, Diary 1965-1966, 16 March 1966.

${ }^{52}$ DBA, Diary 1965-1966, 17 March 1966.

${ }^{53}$ DBA, Diary 1965-1966, 20 March 1966.
}

F. Ferretti, 2020: "Travelling in scholarly lifeworlds: new perspectives on (post)humanism, situated subjectivities and agency from a travel diary", Annals of the American Association of Geographers doi: 10.1080/24694452.2020.1715197 
(1903-1990), another friend of the South-Americans (Ferretti 2018b). Anne's recollections of them were emphatic: "They have a very interesting program on the Pays d'Outre-Mer, and Lasserre is a real gent, God bless him!". ${ }^{54}$ The same page of the diary exposes how relation always strongly mattered to Buttimer: while she dispensed praise for the kindness of Lasserre and his family, a different note concerned another guest of the Department. "Lasserre arrived with another visitor: Herault [arguably Jean-Marcel Hurault - 1917-2005], from Paris.... H. is outrightly hostile. He gave a speech on the Bamileke (Chad), developed a headache and was very obnoxious". ${ }^{55}$ Amazingly, Hurault, a French colonial cartographer in Africa and Guyana, was recently quoted in reference to his positivistic views of cartography and some unpleasant remarks on indigenous peoples (Ferretti 2017). The emotional perception of potential enemies or allies can precede rationality: the technocrat and the future humanistic geographer were wary of each other at their first meeting, despite one can presume that they were only superficially informed about their respective activities.

Travelling back to the north of France, Buttimer stopped at Rennes, where she missed André Meynier, an important figure in French rural geography and the author of one of the earliest histories of French geography (Meynier 1969), but had an occasion to visit "the Philipponneau's house ... they were amazed and most cordial". ${ }^{56}$ Again, a relationship was formed through committed people, though just the day before some colleagues of Philipponneau had warned Buttimer against him: “[A] socialist [he] can't get along with others". ${ }^{57}$ In Paris, Buttimer saw Gabriel le Bras (1891-1970), an elderly sociologist of

\footnotetext{
${ }^{54}$ DBA, Diary 1965-1966, 21 March 1966

${ }^{55}$ DBA, Diary 1965-1966, 21 March 1966.

${ }^{56}$ DBA, Diary 1965-1966, 23 March 1966.

${ }^{57}$ DBA, Diary 1965-1966, 22 March 1966.
}

F. Ferretti, 2020: "Travelling in scholarly lifeworlds: new perspectives on (post)humanism, situated subjectivities and agency from a travel diary", Annals of the American Association of Geographers doi: 10.1080/24694452.2020.1715197 
religions. "He is a very old kindly gent, canon lawyer, full of his own work. He allowed me to read Deffontaines' Géographie et religions". ${ }^{58}$ For scholars of Buttimer's generation, an important constraint was the material availability of books, especially those published overseas. While today the increasing digitalization of journals, books and archives (or inter-library loans and online sales at worst) has reduced the need for documentary mobility, until recent times hunting down a certain book could be an adventure, and Buttimer's visits to French bookshops and libraries (including colleagues' private collections) were part of her construction of a scholarly lifeworld.

This was paralleled by "pilgrimages", such as those Buttimer undertook to see the families of Brunhes and then Max Sorre. "Madame Sorre is an old embittered dear little lady, who feels the world has cheated her husband (partly true). His son, Maurice Sorre, and his wife welcomed me to afternoon tea and we chatted at great length on the Maestro". ${ }^{59}$ Sorre, whose position was relatively central to the post-Vidalian generation, was a scholar likewise interested in social geography and whose scholarly output is the object of recent research work in France, mainly thanks to the $\mathrm{PhD}$ thesis of Dylan Simon (2017). That day, Buttimer took detailed notes that expose how a reflection on the history of geography was key for her entire elaboration, starting with the values of scholars' biographies (Jones 2019).

From Paris, Buttimer did a last call at Rennes and then returned to Belgium, but she had the occasion to do new shorter and targeted trips to France in the following couple of months. She

\footnotetext{
${ }^{58}$ DBA, Diary 1965-1966, 25 March 1966

59 DBA, Diary 1965-1966, 27 March 1966.
}

F. Ferretti, 2020: "Travelling in scholarly lifeworlds: new perspectives on (post)humanism, situated subjectivities and agency from a travel diary", Annals of the American Association of Geographers doi: 10.1080/24694452.2020.1715197 
had a "marvellous chat" with Paul Claval in Paris ${ }^{60}$ and met Pierre Flatrès and especially Philippe Pinchemel (1923-2008) in Lille. ${ }^{61}$ The founder of the IGU Commission on the History of Geography as well as of the Paris Equipe EHGO - Epistémologie et Histoire de la Géographie, Pinchemel was one of Buttimer's main French correspondents and collaborators along with his wife Geneviève, and their surviving correspondence suggests that the international circuits of historians of geography owe much to these scholars. ${ }^{62}$ In March 1966, less than one month's time, Buttimer performed an impressive scholarly Tour de France along the Caen-Paris-Lyons-Grenoble-Montpellier-Toulouse-Bordeaux-Rennes-Paris circuit, seeing geographers, departments, books, landscapes and experiencing the "inside stories" of French geography.

It is possible to conclude that, even though circumstances and external agencies complicated trajectories that were often decided from one day to the next, the prickly and stubborn agency of the subject writing this diary and the directions that she intended to take in her scholarly career played some role revealed by "intimate" writing, starting with the emotions and circumstances affecting these travels and experiences. Other recent views on Buttimer's biography can provide further examples on how her life experiences often exceeded the original subject's willingness, eventually including her decision to quit her religious order some years later, a process on which only further studies can shed more light (Ferretti and Jones 2018; Jones 2019).

\footnotetext{
${ }^{60}$ DBA, Diary 1965-1966, 14-15 May 1966.

${ }^{61}$ DBA, Diary 1965-1966, 8-10 July 1966. Few final pages related to a later summer holiday will not be treated, going beyond the scope of this paper.

${ }_{62}$ DBA, Buttimer correspondence, Folder France.

F. Ferretti, 2020: "Travelling in scholarly lifeworlds: new perspectives on (post)humanism, situated subjectivities and agency from a travel diary", Annals of the American Association of Geographers doi: 10.1080/24694452.2020.1715197
} 


\section{Conclusion}

This paper has highlighted some elements of Buttimer's own scholarly lifeworlds which complicate any easy caricature of her work. Furthermore, primary sources lying at the very beginning of what has been called "humanistic geographies" can substantiate claims to build bridges between this tradition, often associated with phenomenology and existentialism, and later trends in post-phenomenology and anti/posthumanism. Matching views from authors who recently argued for a varied and inclusive notion of "new humanism", I have argued that these travel notes from Anne Buttimer demonstrate the situatedness and in-becomingness of subjectivities. All this provides new arguments to claim that the destabilisation of the subject through its complex relations with external agencies does not imply the complete vanishing of human subjects and their intentionality. In this process, the mobility of subjects and their situated (spatially, historically and culturally) and relational nature is crucial in reconsidering the relational interplay of subjectivities and circumstances. In this relational context, circumstances and materialities are not a simple scenario but an assemblage of elements equally necessary and consubstantial to the negotiated building of these (eventually scholarly) lifeworlds, participating in the construction of careers and in the conception of bright ideas beyond subjective intentionality. This work also shows how, for "humanists" like Buttimer, the human subject was never the oppressive and excluding entity that some simplified readings present today.

An important part of this "new humanism" can be represented by emotional geographies. As claimed by Moss and Donovan, feelings and intimate writings "challenge power by examining the banalities of everyday life" including "connections among people, nonhuman entities and non-living things" (Moss and Donovan 2017, 228). Stressing the political value of feminist

F. Ferretti, 2020: "Travelling in scholarly lifeworlds: new perspectives on (post)humanism, situated subjectivities and agency from a travel diary", Annals of the American Association of Geographers doi: 10.1080/24694452.2020.1715197 
approaches, these authors acknowledge the subversive potential of intimacy writing as "part of a collective political project, one that contests oppressive power relations and seeks to transform society" (Moss and Donovan 2017, 235). They match Lejeune's arguments that intimate writing is not a naïve confession: eventually, Buttimer's later interventions to order her diary to keep a rational record for what Lejeune defines as a hypothetic projection of one's future self (Lejeune 2009) demonstrates that her writing was spontaneous but not ingenuous and served as an instrument for her personal and professional development. This suggests that humanistic traditions, at least in Buttimer's version, should be more considered by current scholarship on emotions and intimate writing, where several themes that she addressed are discussed without always quoting her works.

While a diary cannot be a neutral source, as it clearly implies some centrality of the writing subject, it can still be read non-representationally, analysing the circumstances that it reveals and their relational nature suspended between familiar, professional, political and religious networks frequented by young Anne Buttimer. At the same time, the immediacy of these travel notes' style can match (at least partially) scholarship addressing writing as an exercise blurring artificial divides between theory and practice, between the subject and the world (Williams et al. 2019). This approach produces a fruitful dialogue with Buttimer's published output, especially considering that she was one of the first "explorers" of lifeworlds, a notion that is still informing current debates. Far from pretending to come back to the anthropocentric centrality of a stable and essentialised human subject, I would conclude that the example of scholars' lifeworlds can provide insights about the importance of rethinking human agency, subjectivity, and freedom in constructing “worlds" in McCormack's sense, or after Ash and Simpson's ideas on embodiment, where “'human consciousness' does not take place 'in' the F. Ferretti, 2020: "Travelling in scholarly lifeworlds: new perspectives on (post)humanism, situated subjectivities and agency from a travel diary", Annals of the American Association of Geographers doi: 10.1080/24694452.2020.1715197 
bodies of the human but 'with' the dense scaffolding of things that enables and shapes human thought" (Ash and Simpson 2016, 63). Especially in the case of scholars like Buttimer who deem their work something like a vocation or a mission rather than a mere job, scholarly worlds are something more than a professional realm as they affect scholars' personal, emotional and ethical worlds, always in relation with those of other individuals and with material circumstances and emotions. This also confirms the importance of studying contextual and circumstantial biographies of scholars.

Finally, this diary shows how ground-breaking scholarship is nourished by internationalism, cosmopolitanism and multilingualism, and challenges monolingualism, provincialism and parochialism. This was explicitly claimed by Buttimer in her works on academic migrants from the Middle Ages onwards, and it was relationally put in place in her biography as exposed above. These events in travel and constant mobility, where "experiences of home, reach, and journey continue to offer challenge and surprise" (Buttimer 2001, 40), can destabilise notions of allegedly conservative humanistic understandings of dwelling and "being-in-the-world", which are better expressed by mobility and encounter, at least in Buttimer's case.

\section{Acknowledgements}

I would first acknowledge the Buttimer family, and especially Andreas and Jane Buttimer, for their constant support in this research. I especially thank Francesco Ventura, who first drew my attention on this document when we started opening archival boxes replete with Anne's archival treasures, and the UCD colleagues who are collaborating with the project of fostering Anne Buttimer's intellectual legacy, especially Arlene Crampsie and Alun Jones. I also owe a lot to a number of international scholars with whom I had conversations about Anne's networks

F. Ferretti, 2020: "Travelling in scholarly lifeworlds: new perspectives on (post)humanism, situated subjectivities and agency from a travel diary", Annals of the American Association of Geographers doi: 10.1080/24694452.2020.1715197 
and documents, phenomenology, humanism and post-humanism. It would be impossible to list all of them here, but I would like to mention at least Marcus Power, Derek Mc Cormack, David Seamon, Marcella Schmidt di Friedberg and Vincent Berdoulay. Also great thanks to the three anonymous referees for the Annals and to the editor, Nik Heynen, for their great remarks and suggestions.

\section{Funding}

This research was supported by University College Dublin with the Output Based Research Support Scheme (OBRSS) for 2019, grant number R16208.

\section{References}

Adams, P.C., Hoelscher, S and K.E. Till. 2001. Textures of place: Exploring humanist geographies. Minneapolis: University of Minnesota Press.

Ash, J. and P. Simpson. 2016. Geography and Post-phenomenology. Progress in Human Geography. 40 (1):48-66.

Anderson, B. and P. Harrison. 2010. The promise of Non-Representational Theories. In Taking-place: non-representational theories and geography eds B. Anderson and P. Harrison 1-34. Farnham: Ashgate.

Bataillon, C. 2006. Six géographes en quête d'engagement: du communisme à l'aménagement $\mathrm{du}$ territoire[Six geographers seeking engagement: from communism to territorial planning]. Cybergeo http://cybergeo.revues.org/1739

Bondi, L., Davidson, J. and M. Smith, 2007. Introduction. Geography's 'emotional turn'. In Emotional geographies eds. J. Davidson, L. Bondi and M. Smith 1-18. Burlington: Ashgate. Buttimer, A. 1968. French Geography in the sixties. Professional Geographer 20 (2):134-145. F. Ferretti, 2020: "Travelling in scholarly lifeworlds: new perspectives on (post)humanism, situated subjectivities and agency from a travel diary", Annals of the American Association of Geographers doi: 10.1080/24694452.2020.1715197 
—. 1969, Social space in interdisciplinary perspective. Geographical Review 54 (3):417-426.

—. 1971. Society and milieu in the French geographic tradition. Chicago: Rand McNally and

Co.

—. 1974. Values in geography. Washington: AAG Commission on College Geography.

— 1976. Grasping the dynamism of lifeworld. Annals, Association of American Geographers 66 (2):277-292.

—. 1993. Geography and the Human Spirit. Baltimore and London: John Hopkins University Press.

—. 2001. Home-reach-journey. In Placing Autobiography in Geography ed. P. Moss 22-41. Syracuse: Syracuse University Press.

— 2016. Retirement? You must be joking. The Arab World Geographer 19 (1-2):2737.

Castree, N. and C. Nash. 2006. Posthuman geographies. Social and Cultural Geography 7 (4):501-504.

Clout, H. 2017. Anne Buttimer 31 October 1938 - 15 July 2017. The Geographical Journal $183(4): 455-456$.

Cresswell, T. 2013. Geographic thought: A critical introduction. Chichester: WileyBlackwell.

Davidson, J. and C. Milligan. 2004. Embodying emotion, sensing space: introducing emotional geographies Social and Cultural Geography 5(4):523-532.

Delgadillo, J. 2015. Por una Geografia humanista: Angel Bassols Batalla [For a humanist geography: Angel Bassols Batalla]. Mexico: UNAM.

Donovan, C. and P. Moss. 2017. Muddling intimacy methodologically. In Writing intimacy into feminist geography eds. P. Moss and C. Donovan 3-30. London and New York: Routledge. F. Ferretti, 2020: "Travelling in scholarly lifeworlds: new perspectives on (post)humanism, situated subjectivities and agency from a travel diary", Annals of the American Association of Geographers doi: 10.1080/24694452.2020.1715197 
Dresch, J. 1979. Un géographe au déclin des empires [A geographer at the decline of empires]. Paris: Maspero.

El Gharbaoui, A. 1978. Recherche géographique et engagement politique au Maroc [Geographical research and political engagement in Morocco]. Hérodote 11:86-97.

Ferretti, F. 2017 Tropicality, the unruly Atlantic and social utopias: the French explorer Henri Coudreau (1859-1899). Singapore Journal of Tropical Geography 38 (3):332-349.

—. 2018a. Anarchy and geography. Reclus and Kropotkin in the UK. Abingdon: Routledge.

—. 2018b. Geographies of internationalism: radical development and critical geopolitics from the Northeast of Brazil. Political Geography 63:10-19.

—. 2019. Between Radical Geography and Humanism: Anne Buttimer and the International Dialogue Project Antipode, varly https://onlinelibrary.wiley.com/doi/abs/10.1111/anti.12536

Ferretti, F. and A. Jones. 2018. Anne Buttimer. 1938-2017. Geographers. Biobibliographical Studies 37:13-40.

Harrison, P. 2008. Corporeal remains: Vulnerability, proximity, and living on after the end of the World. Environment and Planning A 40 (2):423-445.

— 2009 In the absence of practice. Environment and Planning D: Society and Space 27 (6):987-1009.

Hawkins, H., Cabeen, L., Callard, F., Castree, N., Daniels, S., DeLyser, D., Munro Neely, H. and P. Mitchell. 2015. What might GeoHumanities do? Possibilities, practices, publics, and politics GeoHumanities 1 (2):211-232.

Jones, M. 2018. Anne Buttimer's The Practice of Geography: Approaching the history of geography through autobiography Geografiska Annaler: Series B, Human Geography early view: https://www.tandfonline.com/doi/abs/10.1080/04353684.2018.1544468

F. Ferretti, 2020: "Travelling in scholarly lifeworlds: new perspectives on (post)humanism, situated subjectivities and agency from a travel diary", Annals of the American Association of Geographers doi: 10.1080/24694452.2020.1715197 
Jones, O. 2007. An ecology of emotion, memory, self and landscape. In Emotional geographies eds. J. Davidson, L. Bondi and M. Smith 205-218. Burlington: Ashgate.

Lejeune, P. 2009. On diary. Honolulu: University of Hawaii Press.

Ley, D. and M. Samuels. 1978. Humanistic geography, prospects and problems. London: Croom Helm.

Lorimer, H. 2003. Telling small stories: spaces of knowledge and the practice of geography. Transactions of the Institute of British geographers 28 (2):197-217.

—. 2019. Dear departed: Writing the lifeworlds of place, Transactions of the Institute of British geographers (44):331-345.

Lorimer, J. 2009. Posthumanism/posthumanistic geographies. In International encyclopaedia of human geography eds. R. Kitchin and N. Thrift 344-354. London: Elsevier.

Maddrell, A. 2009. An interview with Anne Buttimer: an autobiographical window on geographical thought and practice 1965-2005 Gender, Place \& Culture 16 (6):741-765.

McCormack, D.P. 2003. The event of geographical ethics in spaces of affect Transactions of the Institute of British Geographers 28:488-507.

- 2016. The circumstances of post-phenomenological life worlds Transactions of the Institute of British Geographers 42:2-13.

Meynier, A. 1969. Histoire de la pensée géographique en France: 1872-1969 [History of geographical thought in France: 1872-1969]. Paris: Presses Universitaires de France.

Moss, P. and C. Donovan. 2017. Intimate research act. In Writing Intimacy into Feminist Geography eds. P. Moss and C. Donovan 227-235. London and New York: Routledge.

Orain, O. 2009. De plain-pied dans le monde: écriture et réalisme dans la géographie française au XXe siècle [Seamlessly in the world. Writing and realism in twentieth century French geography]. Paris: L’Harmattan.

F. Ferretti, 2020: "Travelling in scholarly lifeworlds: new perspectives on (post)humanism, situated subjectivities and agency from a travel diary", Annals of the American Association of Geographers doi: 10.1080/24694452.2020.1715197 
Pickles, J. 1987. Geography and humanism. Norwich: Geo.

Popkin, J.D. 2009. Philippe Lejeune, explorer of the diary. In P. Lejeune. On diary. Honolulu: University of Hawaii Press: 1-15.

Rak, J. 2009. Dialogue with the future: Philippe Lejeune's method and theory of diary. On diary. Honolulu: University of Hawaii Press: 16-28.

Roberts, T. 2019. Writing. Transactions of the Institute of British Geographers 44 (4): 644646.

Robic, M.C., Tissier, J.L. and P. Pinchemel. 2011. Deux Siècles de géographie française: une Anthologie [Two centuries of French Geography: an anthology]. Paris: Editions du CTHS.

Rose, M. 2006. Gathering dreams of presence: A project for the cultural landscape. Environment and Planning D: Society and Space 24 (4):537-554.

—. Pilgrims: an ethnography of sacredness. cultural geographies 17 (4):507-524.

Seamon, D. 2018. Life takes place: Phenomenology, lifeworlds and place making. London: Routledge.

Simon, D. 2017. Les inscriptions savantes de Maximilien Sorre (1880-1962) entre conformation et singularisation dans le champ de la géographie [The intellectual belongings of Maximilien Sorre (1880-1962) between standardisation and singularization in geography]. Paris: $\mathrm{PhD}$ dissertation.

Simonsen, K. 2005. Sensations, space and time: The contribution from Henri Lefebvre. Geografiska Annaler. Series B, Human Geography 87 (1):1-14.

—. 2013. In quest of a new humanism: Embodiment, experience and phenomenology as critical geography. Progress in Human Geography 37 (1):10-26.

Simpson, P. 2015. What remains of the intersubjective: On the presencing of self and other. Emotion, Space and Society 14:65-73.

F. Ferretti, 2020: "Travelling in scholarly lifeworlds: new perspectives on (post)humanism, situated subjectivities and agency from a travel diary", Annals of the American Association of Geographers doi: 10.1080/24694452.2020.1715197 
— 2017. Spacing the subject: thinking subjectivity after non-representational theory. Geography Compass 11 (12):e12347.

Smith, J.M. 2009. Humanism/Humanistic geography. In International encyclopaedia of human geography eds. R. Kitchin and N. Thrift 239-250. London: Elsevier.

Smith, M., Davidson, J. and V. Henderson. 2012. Spiders, Sartre and 'magical geographies': the emotional transformation of space Transactions of the Institute of British Geographers 37 (1):60-74.

Smith, S. 2016. Intimacy and angst in the field Gender, Place and Culture 23 (1):134-146.

Thrift, N. 2004. Intensities of feeling: towards a spatial politics of affect Geografiska Annaler:

Series B, Human Geography 86:57-78.

—. 2008. Non-representational theory: space, politics, affect. London: Routledge.

Tuan, Y.F. 1976. Humanistic Geography. Annals of the Association of American Geographers $66(2): 266-276$

Whatmore, S. 2002. Hybrid geographies, natures, cultures, spaces. London: Sage.

Williams, N., Patchett, M., Lapworth, A. Roberts, T. and T. Keating. 2019. Practising posthumanism in geographical research. Transactions of the Institute of British Geographers 44 (4):637-643.

Wylie J.W. 2012. Dwelling and displacement: Tim Robinson and the questions of landscape. cultural geographies 19 (3):365-383.

—. 2010. Non-Representational subjects? In Taking-place: non-representational theories and geography eds B. Anderson and P. Harrison, 99-115. Farnham: Ashgate

- 2009. Landscape, absence and the geographies of love. Transactions of the Institute of British Geographers 34 (3):275-289.

F. Ferretti, 2020: "Travelling in scholarly lifeworlds: new perspectives on (post)humanism, situated subjectivities and agency from a travel diary", Annals of the American Association of Geographers doi: 10.1080/24694452.2020.1715197 


\section{Author's biography}

Federico Ferretti received his PhD from the Universities of Bologna and Paris 1 PanthéonSorbonne in 2011. After research and teaching experiences in Italy, France, Switzerland and Brazil, he is now Associate Professor in the School of Geography at University College Dublin (UCD), Belfield - Dublin 4, Ireland. E-mail: federico.ferretti@ucd.ie. His research and teaching interests lie in philosophy and history of geography and on international circulation of geographical knowledge through critical, decolonial and anarchist approaches, with a special focus on Latin America and the Global South.

F. Ferretti, 2020: "Travelling in scholarly lifeworlds: new perspectives on (post)humanism, situated subjectivities and agency from a travel diary", Annals of the American Association of Geographers doi: 10.1080/24694452.2020.1715197 